
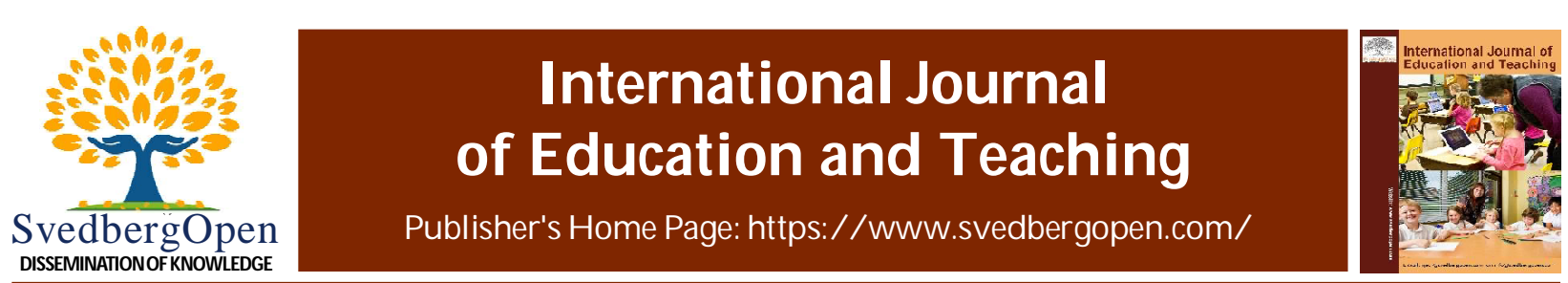

\title{
The Berlin ritual and gesture study. A contribution to pedagogical anthropology
}

\section{Christoph Wulf ${ }^{*}$}

${ }^{1}$ Free University of Berlin, Habelschwerdter Allee 45, Berlin, Berlin 14195, Germany. E-mail: christoph.wulf@fu-berlin.de

\section{Article Info}

Volume 1, Issue 2, June 2021

Received : 03 January 2021

Accepted : 21 May 2021

Published : 05 June 2021

doi: 10.51483/IJEDT.1.2.2021.16-29

\begin{abstract}
The Berlin Study of Rituals and Gestures is a case study in pedagogical anthropology built on a comprehensive understanding of anthropology. It examines the role of rituals and gestures in the four central fields of socialization: family, school, peer group, and media and contributes to the understanding of the importance of rituals in education. It focuses the mimetic, social and performative character of rituals and gestures. In my view anthropology is not only cultural anthropology/ethnology. Anthropology is a decentralized, polycentric field of research in which problems of representation, interpretation, construction, deconstruction, and thus methodological diversity are of central importance. Significant are the following paradigms of Anthropology: evolution/hominization, philosophical anthropology, historical Anthropology, cultural anthropology to find out how to understand the human being in the globalized world of the Anthropocene. Anthropology is characterized by a dual historicity and culturality, that arises from the historicity and culturality of the different perspectives of anthropological researchers and from the historical and cultural character of the contents and subjects of research. Anthropological research often is interdisciplinary and transdisciplinary as well as intercultural and transcultural. Anthropology employs diachronic, synchronic and philosophical methods to investigate human societies and cultures.
\end{abstract}

Keywords: Educational anthropology, Pedagogical anthropology, Hominization, Philosophical anthropology, Historical anthropology, Cultural anthropology, Ritual, Performativity, Mimesis, Practical knowledge

(C) 2021 Christoph Wulf. This is an open access article under the CC BY license (https://creativecommons.org/licenses/by/4.0/), which permits unrestricted use, distribution, and reproduction in any medium, provided you give appropriate credit to the original author(s) and the source, provide a link to the Creative Commons license, and indicate if changes were made.

\section{Introduction}

Since the very beginnings of Western thought, anthropology and pedagogy have been linked. Even though the term "anthropology" was only coined in the $16^{\text {th }}$ century, and even though using it anachronistically, avant la lettre, is somewhat problematical, the resonance between pedagogy and anthropology is manifest in Plato's Republic as well as in the writings of St. Augustine and St. Thomas of Aquinas. This resonance cannot be denied: neither in the $17^{\text {th }}$ century in the works of Comenius, nor in the $18^{\text {th }}$ century in the writings of Rousseau and Pestalozzi nor yet in the $19^{\text {th }}$ century in Kant's, Herbart's, Humboldt's and Schleiermacher's oeuvre. In the course of the $20^{\text {th }}$ century, anthropology and anthropological modes of observation grew steadily in influence in numerous academic disciplines, and particularly within philosophy. Max Scheler sees the starting point of this interest in anthropology in the following situation: In

\footnotetext{
* Corresponding author: Free University of Berlin, Habelschwerdter Allee 45, Berlin, Berlin 14195, Germany.

E-mail: christoph.wulf@fu-berlin.de
} 
about 10,000 years of history, our era is the first in which man has become "problematical" through and through, but also the first in which he does not know what he actually is, and at the same time knows he does not know. That situation constitutes the starting point of pedagogical anthropology, which has, since the second half of the $20^{\text {th }}$ century, developed into the most important field of educational knowledge.

According to Immanuel Kant the human situation is as follows: What human beings are depends thus on what they must be and on what they may be. Human beings are nothing by and of themselves and must make themselves into who they are and turn themselves into who they must become, whilst in so doing they frequently hurl themselves against their very own limits. The study and categorization of these relationships and interconnections constitute, for Kant, the duty of pragmatic anthropology (cf. Kant, 1982). In contrast to physiological anthropology, which examines the biological conditions of human existence, pragmatic anthropology studies the field of human action and human freedom.

If we wish to discharge of this duty properly, it is first necessary to resolve one question: what is it that we understand, today, under anthropology? What meaning does this term have for the humanities? As I see it, anthropology today can only be developed within the framework of the historical, ethnological and philosophical study of human beings, that is to say as historical cultural anthropology. It must be guided by a careful reflection of the manner in which anthropology may be conducted after the death of God (Nietzsche), that is to say in the wake of the disappearance of universal anthropology, and after the "death of man" (Foucault), in the sense of that abstract and European masculine being which served as the template for conceptualizing the individual.

\section{Anthropological paradigms}

If we wish to put the epistemology of pedagogical anthropology on a more profoundly reflected footing, then a confrontation, at once critical and constructive, with the anthropological paradigms which are internationally significant is absolutely indispensable (Wulf, 2013; 2022a). Speaking about anthropology in the humanities and social sciences, we are thus referring to:

- Anthropology of evolution and hominization?

- Philosophical anthropology developed in Germany

- Historical anthropology and the history of mentalities, initiated by historians in France and taking its cue from the Annales-School

- The American tradition of cultural anthropology and

- Historical cultural anthropology.

In order to provide a framework for educational anthropology I suggest that we use the paradigm of historical cultural anthropology as a basis for further research. This paradigm integrates perspectives from the other four major anthropological paradigms and provides a basis for an adequate understanding of educational phenomena, processes and institutions in a globalized world. I shall focus on diachronic and synchronic perspectives and historical and cultural research within educational anthropology. Due to the limitations of space I have selected just one of the major research projects in the field of historical cultural anthropology in Germany to present to you. This project serves as an example of ethnographic research in education. Together with historical and philosophical methods, the ethnographic approach is one of the main methods of educational anthropology, conceived as historical and cultural anthropology (Wulf, 2002 and 2013).

\section{Anthropology of evolution and hominization}

As the branch of anthropology devoting itself to the study of evolution hominization stems from an attempt to fit the natural history of human beings into the horizon of anthropology in order to understand the "lost paradigm" which the human is (Morin, 1973). On the other hand, the natural history of human's evolution can only be understood when considered as part of history. Its irreversibility, as well as that of the history of life itself, is grasped today as a consequence of material self-organization (Eigen and Ruthild, 1992; Weinberg, 1993), which also represents a facet of reflexive historical cultural anthropology. Just like anthropology stresses the historical character of the way it frames its problems and of its analyses, the theory of evolution insists on the radical chronologization of nature and of the natural history of the evolution of human beings. Time and history are thus central dimensions of evolution. Hominization is the long process of evolution, from Australopithecus to primitive man, from Homo erectus to the modern representatives of our species, which unfolds as a multi-faceted morphogenesis arising from the combined effects of ecological, genetic, cerebral, social and cultural factors. 
Hominization can be understood as a multi-dimensional morphogenesis arising from the interplay between ecological, genetic, cerebral, social and cultural factors. Current understanding is that this process necessitated three types of change. The first were ecological changes which led to the expansion of the savannah and thus to an "open" biotope. Second, a genetic change took place in the highly developed primates which were already walking upright. Third, there was a change in social self-reproduction due to the splitting off of young groups and the use of new territories. The new biotopes led to significant increases in the requirements for dexterity and communication skills for the two-handed bipedal life-forms which were already able to use and manufacture simple tools. These hominids who had become omnivores, had to develop new levels of alertness, watchfulness and cunning to cope with the demands of hunting. They needed new forms of co-operation and social responsibility to protect themselves against predators, search for food, hunt and divide their prey and rear their young. This led to a further development in cerebral capabilities. It was therefore the new ecosystem - the savannah-, which triggered the dialectic between the feet, hands and brain and which became the source of technology and all other human developments. As these processes unfolded, a paleosociety developed with a culture-based division of work between men and women and the development of hierarchical social relations. Language and culture became gradually more complex. The process of hominization was intensified by a prolonged youth or neoteny, incomplete development of the brain at birth and prolonged childhood with longer affective ties between the generations, with the associated potentials for comprehensive cultural learning. The cerebralization, prolonged youth and increased social and cultural complexity were mutually dependent. The complexity of the brain requires a corresponding socio-cultural complexity. The creative potential of the brain can only be expressed and develop in a socio-cultural environment that grows in parallel. This dialectic relationship means that humans have been cultural beings from the very beginning, i.e. their "natural" development is cultural. The final stage of this process of hominization is, in fact, also a beginning. The human species, which has reached its completion in Homo sapiens, is a youthful and childlike species, our brilliant brains would be feeble organs without the apparatus of culture, all our capabilities need to be bottle-fed. Hominization was completed with the irreversible and fundamental creative incompleteness of human beings. The course of hominization clearly illustrates that Homo sapiens and Homo demens are inseparably linked and the great achievements of humankind have their downside: the horrors and atrocities perpetrated by humanity (Wulf, 2013).

\section{Philosophical anthropology}

While taking evolution into account in anthropology serves to highlight the shared lineage and mutual parentage of all forms of life and the long time-span of hominization as well as the general laws of evolution, philosophical anthropology turns its attention to the particularity of "human being's" character.

The centerpieces of philosophical anthropology are the anthropological works of Max Scheler, Helmuth Plessner and Arnold Gehlen. Despite considerable differences between these authors, their works of the first half of the $20^{\text {th }}$ century are referred to collectively as philosophical anthropology. Their common purpose was to establish how human beings differ from animals, what the specific conditions of being human are and to define the human condition. Despite their differences, all three authors were in agreement that the central focus of anthropology is the human body which is in itself the starting point for differentiating between humans and animals. In a time when humans had come to have grave doubts about themselves and were aware of this, it was hoped that by focusing on the body, knowledge gleaned from natural sciences could serve as a starting point for a revalidation of human nature. This orientation was associated with a rejection of idealism and the philosophy of consciousness. Philosophy was no longer interested in reason, but in the creative diversity of life.

In 1927, Max Scheler gave a lecture in Darmstadt entitled, "Die Sonderstellung des Menschen" (The Human Place in the Cosmos), which was published in 1928 under the title Die Stellung des Menschen im Kosmos (Man's Place in Nature) and is regarded as the beginning of philosophical anthropology. When Scheler died in the same year he left no concrete preparatory material for the anthropological work he had intended to publish in 1929. The philosopher and biologist Helmuth Plessner, however, published his main anthropological work Die Stufen des Organischen und der Mensch (Levels of Organic Being and Man) in 1928. Despite large differences in material and argument, Scheler's article and Plessner's book share the assumption that organic life is structured in levels. Arnold Gehlen's work Der Mensch, seine Natur und seine Stellung in der Welt (Man: His Nature and Place in the World) took a different approach and focuses on humans as acting beings.

The preoccupation of this strand of anthropological thought was to understand the essence, the nature of human beings in general. Within this framework, anthropology concentrated upon a comparison between "man" and animal (Gehlen, 1988; Plessner, 1970), with a view to distinguishing shared features and differences. To grasp the conditio 
humana philosophical reflections were brought to bear upon biological insights. It was thought that the conditions for the formation of the human species could be glimpsed in such biological and above all morphological characteristics. This perspective has had two consequences. On the one hand, the focus of anthropological reflection and research has from then on shifted onto the human body. On the other hand, the development of a generalizing discourse relating to one unique and unitary model of "human being" could be observed. While the latter seems appropriate for attributing typical characteristics to a species, such as walking upright, it ceases to make sense once this narrow focalization is relinquished and anthropology is stretched to accommodate the historical and cultural reality of human's existence.

Due to its focus on the human being as such, philosophical anthropology fails to address the historical and cultural diversity of human beings in the plural. This is the inevitable consequence of the interesting attempt to develop a single coherent concept of "human being", which failed to capture the diversity of human life and could hardly have achieved its ambitious goals. To investigate this is the aim of a branch of historical science that is oriented towards anthropological issues.

\section{The Annales School and the history of mentalities}

Anthropology underwent an additional development and refinement in a historical turn, which can be discerned in the historical treatments of anthropological topics of the Annales School and the history of mentalities which flowed from it (Burke 1991; Ariès/Duby 1985). Historiographically, this alignment with anthropological themes and topics represents a novel orientation. It completes the representation and analysis of the dynamic of historical events and of socioeconomic conditions effected by structural and social history. From concentrating on anthropological themes and topics, inquiries turned increasingly to interrogating actual social structures as well as the subjective elements of the social individual's actions. In this vein, elementary types of human behavior and basic situations are analyzed. Quite opposed to those hypotheses which insist that these basic situations be rooted in a character common to all human beings, the practitioners of historical studies with an anthropological orientation inquire into the specifically historical and cultural character of each of these phenomena. Fernand Braudel's study of the Mediterranean (Braudel, 1949), Emmanuel Leroy Ladurie's on the village of Montaillou, Carlo Ginzburg's on the world of millers around 1600 (Ginzburg, 1980) may be cited as successful examples for this endeavor. The research into fundamental human experiences or into the history of mentalities, which has been undertaken in connection with this historical turn, is inevitably less rich in detail. Often, this is due to the limits which the insufficiency of sources imposes upon the possibilities of historical knowledge, which is born of the tension between event and account, reality and fiction, structural history and narrative historiography. A precise delimitation of narrative and description is impossible: historiography represents both controlled fiction and controlled construction.

Historical anthropology investigates elementary situations and basic experiences of being human. It studies a basic stock of patterns of thought, feeling and behavior that is anthropologically constant (Dinzelbacher, 1993), basic human phenomena (Martin, 1994) and elementary human behavior, experiences and basic situations (Medick, 1989). Although it could be understood otherwise, these classifications are not concerned with making statements about humans in general but with gaining an understanding of the multi-dimensional conditions of life and experiences of real people in their respective historical contexts. These anthropological studies are oriented towards investigating the multitude of ways in which the different ways of human life are expressed and presented. This diversity of phenomena is paralleled by the multi-dimensionality and open-endedness of anthropological definitions and research paradigms. In this research it is necessary to develop a feeling for the difference between the historical world under investigation and the current frame of reference of the research. Since, for example, linguistic metaphors and terms have different meanings in different times and in different contexts, these differences in meaning must be taken into account. The same applies with regard to research into basic human behaviors, experiences and fundamental situations. From the point of view of the historical sciences, the feelings, actions and events under investigation can only be understood in terms of their historic uniqueness. It is this that lends them their dynamic nature and makes them subject to historical change.

\section{Cultural Anthropology or Ethnology}

Even though anthropology is the result of a process of philosophical and scientific evolution, it can no longer pretend, these days, that at the end of the day only Europeans exist as "human beings" and act as though putative European humans were the only possible yardstick. It is obvious, even in an era of globalization deeply marked in its content and form by Western culture, that different forms of human life exist today, influenced by various local, regional and national cultures. The Anglo-Saxon tradition of cultural and social anthropology has turned its attention to this situation. Within this framework, the accent lies on the social and cultural diversity of human life. Its research explains both to what extent cultural evolutions are heterogeneous and to what extent the profound diversity of human life remains disregarded. It is 
precisely the analysis of foreign cultures which makes it plain to us how limited and troublesome this understanding is. Comparing human expressions and manifestations across several cultures has demonstrated to what great extent the study of cultural phenomena brings forth new uncertainties and questions. Thanks to the analysis of cultural manifestations drawn from heterogeneous cultures, anthropological inquiries make an important contribution to the elaboration and development of anthropology; while its ethnographical methods oblige practitioners to draw upon historical sources. Quite apart from creating a sensitivity for the strange and foreign character of other cultures, it also creates a sensitivity for that which is strange and foreign in its own culture. The (self-)reflexive point of view adopted by cultural anthropology towards European cultures has contributed to a considerable evolution and advance of anthropological knowledge (Sahlins, 1976; Harris, 2001; Evans-Pritchard, 1965; Malinowski, 1922; Mead, 1950; LéviStrauss, 1992; Hermès 2005).

\section{Historical cultural anthropology}

Being confronted with philosophical reflection has given rise to a critique of anthropology which is constitutive for anthropology in the field of the humanities, and which focuses on the objects, themes and methods of research-based knowledge acquisition. The specific situation of human beings in the world, the comparison with animals or machines, is no longer anthropology's centre of interest. Instead, manifold historical and cultural inquiries focus on studying and understanding the cultural diversity of social life. A particular and very pronounced interest in the study of current phenomena is noticeable. In my understanding, the research undertaken by historical anthropology is no longer the exclusive preserve of the historian, as was still the case within the framework of the Annales School. In the continuity of this broader conception, historical cultural anthropology means an orientation towards the humanities and the social sciences. It touches upon the historical and cultural determination of culture and its manifestations, and demands that their study and reflection take into account ethnological and philosophical perspectives and questions. Committed to this task, historical cultural anthropology makes an important contribution to the self-comprehension and selfinterpretation of cultures and societies today. In this process of cultural understanding, research efforts rapidly run the risk of being unable to move beyond the level of their own initial insights. To safeguard against this risk, historical cultural anthropology needs to reflect upon its relation to power and knowledge, as well as to make efforts specifically aimed at bringing to light the involuntary and often unacknowledged normative implications of its own research. The critique of anthropology is itself a constituent part of historical anthropology, which leads to an epistemological insecurity and once more casts doubt upon the concordance between the name of "man" and the names of the essence, of logic and of the concept of identification, of the reach of hermeneutics, of history (understood as the history of progress and acquisition), and of the subject itself (in so far as it is conceived as the one and only central field of conscience and constitutive in its rapport with the world).

Within this frame of reference, reflexive historical cultural anthropology designates the multiform trans-disciplinary and trans-national efforts to follow up on the universal idea of an abstract anthropological norm and to continue analyzing other human phenomena. Historical cultural anthropology is the common denominator of history and the humanities. Nevertheless, it does not exhaust itself either in a history of anthropology as a discipline nor in making a contribution to history from the perspective of an anthropological sub-discipline. It attempts, rather, to bring into an accord the historical and cultural determination of its perspectives and methods with the historical and cultural determination of its object of study. As a consequence, historical cultural anthropology can harness insights gleaned in the humanities with those yielded by a critique of anthropology based on the history of philosophy, and bring both to fruition in order to create new perspectives and lines of inquiry out of a new consciousness for methodological problems. At the heart of these efforts, an inimitable and voracious agitation of thought and research holds sway. Historical anthropology is limited neither to certain spatial frames nor to particular epochs. Reflecting on its own historicity and its own cultural condition, it succeeds both in leaving behind the eurocentrism of the humanities and the interest in history (antiquarian in the final analysis) as well as in giving precedence to current and future problems (Wulf, 1997, 2002, 2004, 2013; Wulf, and Kamper, 2002).

On the basis of these five paradigms a historical cultural educational anthropology has been developed over the last 20 years and has now become an institutionalized branch in the German Society for Educational Research. The range of research in this field includes a variety of theoretical, historical and empirical studies, the most prominent of which is the Berlin Study on Rituals. This study combines ethnographic research in an inner-city school with conceptual work on the dynamics and performativity of rituals and their potential for engendering social relationships in education and community life. In what follows I shall demonstrate how ethnographic research on rituals contributes to a historical cultural anthropology of education 


\section{The Berlin study on rituals and gestures}

Rituals and ritualizations play a central role in the pedagogy, education and socialization of children. They structure children's lives and support their integration into a social order (Resina and Wulf, 2019). Rituals and gestures shape transitions between fields of socialization and institutions, and facilitate social learning, which is important both during lessons and in the school's broader context. Due to their performativity, pedagogical and educational processes function like rituals and ritualizations in other fields of social action. How children perform their behavior, whether alone or together with adults, can be seen as the performativity of their actions. Important aspects of cultural learning occur by way of mimetic processes. In this, images, schemes, the expectations of others, social situations, occurrences, and actions are incorporated into an individual's world of mental images. This practical knowledge enables children to learn and act together, to live and to be. In the face of globalization and Europeanization, pedagogy and education have become intercultural tasks, for which rituals, ritualizations, pedagogic and social gestures, the performativity of social practices, and mimetic forms of learning play an important role. Ethnography and qualitative research methods are appropriate instruments for investigating rituals and ritualizations as well as the performativity of pedagogic practices, of mimetic processes and of intercultural education processes. Participant observation, video-supported observation, video performance as well as the analysis of photographs, interviews and group discussions have proven to be the most viable methods; they should be combined wherever possible and are key for obtaining complex and methodologically transparent research results.

The results of this ethnographic project are extensive and can only be covered cursorily in the framework of this article. I will therefore summarize five central findings, provide a short description of the study and focus on central categories of rituals in education:

1. Rituals and gestures play a central role in the pedagogy, education, and socialization of primary school children. They structure their lives and aid in their integrating into a social order as well as in constructively working with it. Rituals design transformations between fields of socialization as well as between institutions and facilitate social learning, which is vital in class.

2. Due to their performativity, pedagogic practices such as rituals and ritualizations work in all fields of socialization. The performativity of actions becomes apparent in the way that children perform their behavior and actions either by themselves or together with adults. The performative character of pedagogic and social practices refers to their corporality.

3. Important parts of cultural life among children take place by way of mimetic processes. These facilitate the incorporation of images, schemata and imaginations of other people, social situations, events and actions and integrate them into a mental world of images. The children thereby acquire a practical knowledge that enables them to learn, act, live, and be together.

4. In the face of globalization and Europeanization, pedagogy and education in Europe have taken on an intercultural task, for which rituals and gestures, pedagogic and social gestures, the performativity of social practices as well as mimetic forms of learning play an important role.

5. Ethnography and qualitative methods are useful for the investigation of rituals and gestures, of the performativity of pedagogic practices as well as of mimetic and intercultural processes of education. Participant observation, videobased observation, video-performance, and photo-analysis as well as interviews and group discussions are among the most important research methods; they can be combined and complement each other. This diversity of methods is particularly suited to provide complex and methodically transparent research findings.

Which role do rituals and gestures play in the genesis of the social dimension in people's lives in contemporary society? Answering this question is what the Berlin Study on Rituals and Gestures aims to contribute to, a study which has been conducted over the past 11 years and conceived for a total duration of 12 years (Wulf et al., 2001, 2004, 2007, 2010, 2011). The research focuses upon the importance and meaning of rituals for the learning and education processes of children and adolescents, drawing on rituals from four areas of socialization, namely family (1), school (2), children's and youth culture (3) as well as media (4). Empirically, the study's main focus is on the children of an inner-city elementary school and their families, where the research is confronted with the usual conditions prevalent at such innercity schools: about 300 pupils from 25 different ethnic communities. The school in question is an innovative UNESCO school with an excellent principal and a very active and competent teaching body. 


\section{Families}

In the case of this school, the families whose rituals we studied were convinced of participating in the research, too. Examples of such rituals include the family breakfast, with the help of which the family members each morning reaffirm their mutual devotion and their overall togetherness, as well as children's birthday celebrations, where they, the offspring, i.e. the distinctive feature of the family as opposed to the relationship of a couple, form the celebrated focus of attention. At the same time, a child's birthday party is an important opportunity to celebrate for members of an age cohort, important for the community which they stage and perform on such occasions. The most important of the cyclically recurring family rituals, however, is Christmas, in which the family puts itself on stage and performs itself in relation to the birth of Christ and the unity of the "holy family". Family holidays, too, in which the dross of the everyday is left behind and communal experiences reminiscent of paradise are made_-again, a yearly occurrence_number among these rituals replenishing and renewing the family.

\section{School}

It is obvious that school is a ritual activity, the study of which permits fundamental insights into the relationship of institutions and rituals as well as into relationships of hierarchy and power. Even at the very beginning, during the festivities marking enrolment and graduation, in which transitions are ritually staged and performed, this emerges with great clarity. In the enrolment celebration, the reform pedagogical school we study styles and stages itself as a "school family" with the intent to ease the new pupils' passage from the world of family life and kindergarten into the world of school education. Manifold and multiform are the rituals and gestures by which both the class (which accounts for the greater part of the everyday world of the children whilst at school) and the community of the school are produced. Ritual celebrations of summer, advent, and carnival are part of the normal school classes and the school as a whole, in which dialogues, work, play and celebration are all part of the principles of designing instruction and school life. Next to the rituals enumerated above, we can identify a host of micro-rituals in the everyday routine of teaching and learning at school, in which the interaction between the children as well as that between children and teachers is staged and performed. Each Monday morning, for example, all classes hold a "morning circle", in which the children give one another accounts of what they have experienced and undertaken during the weekend. By going through with this ritual, the passage from the children's familial world on the weekends to the social and academic demands which the school places on its pupils is made tangible. Another ritual (the opening of which many teachers mark with a gong) consists of having the children practice meditative silence, a task which many children relish but which they find far from easy. Teachers and pupils, during teaching and more generally while at school, stage processes of learning and formation in rituals and ritualization and in so doing negotiate and deal with differences between the intentions of the pupils and those of the school as an institution.

\section{Children's and Peer Culture}

The social dimensions of children's and peer culture, too, develop in and abetted by rituals, as evidenced by games the children play during the intervals in the schoolyard during which various groups are formed through inclusion and exclusion. Important determining criteria are: the kind of game played, gender and ethnicity. The scene play of the games played during the breaks produce social groups which remain stable over longer periods and which are more or less open towards new arrivals. Amongst adolescents, break dance and street dance groups and their rituals staged on the sites of open-access community work with youths are particularly popular. The LAN-parties which we investigated, in the context of which many young people gather in large gyms or halls in order to play one another in a certain electronic game, too, exhibited a fixed, ritualized game and group structure.

\section{Media}

In the case of the media-oriented rituals, we started out by investigating ritualized media formats and mises-en-scènes, we attempted, in other words, to work out how ritualized media representation such as advertising, newscasts, talkshows and crime films influence the children's world of imagination. In order to find out which influence such ritualized televised sequences have upon the behavior and the actions of children, we invited them to produce movies themselves, with the aid of a camera and in volunteer work groups where some were actors, others directors and cameramen. It was fascinating to observe during these "shoots", to what degree the ritual structures of German TV imprint themselves upon the collective imagination, the collective world of fancy of these children, traversing all ethnic boundaries. At the present time, we are investigation how the use of personal computers in teaching, in both the official and the unofficial school curriculum informs processes of learning. 


\section{Methods}

In the field of research thus constructed we are working with qualitative methods, allowing us to address the kinds of question the study asks while sticking closely to the objects of inquiry. At the same time, we aim to adapt and develop these tools in the very process of reconstructing and analyzing the empirical data. Part of our inspiration stems from Grounded Theory (Glaser/Strauss, 1969; Strauss/Corbin, 1994) with its plea to understand theory as a process and the recommendations on collecting, coding and analyzing data which ensue. As the performative character of ritual-based processes of learning and education is our central focus, we have chosen methods of inquiry which on the one hand shed light on the mise-en-scène and the staging of ritual actions while at the same time yielding information about the meanings which the participants ascribe to the rituals and about the way they grasp and interpret the learning and education processes embodied within them. In order to attain the first goal, we undertake participatory observation as well as video-based observation. In order to do justice to our second aim, large-scale group discussions and interviews are conducted. Each method yields different kinds of information, which is accordingly coded and interpreted differently. Given the fundamental limitedness of all methods of inquiry and the known advantages and drawbacks of each one, we attempt in many instances to investigate the same ritual actions with the aid of overlapping methodological tools (Flick 2004, 2007; Bohnsack 2003). In the various constituent parts of our study, the methods are combined and weighted differently according to the structure of the specific field of research and the nature of the questions posed within it.

\section{Central functions rituals fulfill}

The following section will examine the most important findings of the performative approach to ritual research in pedagogy and education, where the focus is on the performative arrangement and the practical and bodily side of rituals and ritualized pedagogical and educational practices. It touches on many forms of theoretical and empirical research and demonstrates the complexity of ritual structures and activities and their important role in historical cultural pedagogical anthropology.

1) Rituals, and gestures create social relationships in pedagogy and education. Without rituals, and gestures social relationships and communities would be unthinkable. Educational and social communities are formed in ritualized practices. They are the cause, the action and the effect of rituals and gestures. The symbolic and performative content of ritual practices creates and stabilizes their identity. Rituals and gestures create structures of order where all members of the educational or the social community - albeit with differing levels of influence - help to decide which form these should take. These structures are both real as well as rooted in the imaginary of the participants. They give them a feeling of security as the actions of other ritual participants are predictable. This ritual framework creates the familiarity of the practices of everyday life (Gennep, 1960; Goffman 1986; Tambiah, 1979; Grimes, 1995). Practices outside of this framework seldom occur. When they do occur, their consequences are analyzed or the framework is changed. This framework relates the practices of the ritual participants to each other in a way that they answer each other and thereby create new practices. The extent to which ritual practices can be predicted depends on their spontaneity and playful character. Institutionalized and informal educational and social communities have a collectively shared symbolic knowledge and ritualized forms of interaction where they can perform and modify this knowledge. The repeated staging of this knowledge, which is present in every ritual performance, is a path to selfexpression as well as securing and transforming educational and social order. In this process, dealing with differences to the world outside of the group and the world within the group plays a central role. The group of children deals with the differences in such a way that they do not endanger the community but in a manner whereby they can be beneficial to the group. As a rule, this is done by the repeated staging and performance of the ritual. As this is a joint action, it requires the suppression of differences for the ritual practices to be successful. If such a suppression of differences is not successful and no ritual practice takes place, the community is endangered. Communities are formed in ritual activities as performative communities (Wulf et al., 2001, 2004, 2007, 2010, 2011).

2) During the performative arrangement of rituals, a new social, pedagogical and educational reality is created. This reality is not completely new - previous models of it have existed before, however, it has not been present in this particular form at this particular location before this particular time. Taking earlier rituals and gestures as a basis, every performative arrangement in education creates a new ritual reality and a new ritual community. This ritual community can develop among the children or people who carry out the ritual practices for the first time, but it can also involve a repetition, whereby the community confirms its status as such. The actual performance of rituals or ritual practices is essential for the forming of social and educational communities. The community expresses itself in the performative style of the performance. The ritual and gestural presentation enables the expression of something that cannot be expressed otherwise. Therefore the ritual staging should be seen as a "window" that allows a glimpse 
into the foundations of the community and the culture that creates it. The performative arrangement of rituals in education causes something to become visible that previously could not be seen. A vital aspect of this is that it occurs in the form of a practice that creates a social and an educational reality and which is partially independent of its interpretation.

The staging of rituals and gestures in education is always conducted in the context of previous ritual and gestural performances. However, these can differ enormously. In some cases the relationship between old and new ritual and gestural performances is very close and in other cases very loose. In any case the performance of rituals and ritualized practices constitutes a form of continuity which is vital for the effectiveness of the ritual. Often, the historical continuity stabilizes the order of the community and legitimizes it. Continuity gives rise to the impression that the social or educational situation created in the ritual has always been thus and is therefore "natural". This is frequently used to ensure the continuation of the current distribution of power in societies and to maintain social hierarchies - a matter that requires ideological critical analysis.

3) The performative character yields its full effect in the staging and performative arrangement of rituals and gestures in pedagogy and education (Goffman, 1959, 1986; Geerts 1973, 1993; Schechner, 1977; Turner, 1982, 1969; Bell, 1992; Wulf et al., 2001; Wulf, and Zirfas, 2007). The term staging in this case refers to the way in which the ritual scene is set in education. There is room for maneuver in every ritual performance; this is used in widely differing manners. Forced practices which allow for no deviations are highly infrequent and occur only in pathological cases. The staging of rituals can take many forms. In some cases the staging is spontaneous and can be barely distinguished from the performance itself. A ritual template is used in these cases, however, it is only decided during the actual performance of the ritual how this template is to be used. Spontaneous demonstrations are examples for rituals in education in which staging and performance largely coincide. However, it is still logical to distinguish between staging and performance in these cases. Especially in such cases, the question arises as to who is staging the educational ritual - who is the agent and who is the agency of its performance? Is it a tradition, a group, a person or a collective imaginary and practical knowledge which emerges from the ritual?

4) When discussing the staging and performance of rituals and gestures in pedagogy and education, the bodies of the participants are implicitly involved. How do these appear in a ritual? How do they take their place in the scene? What does their arrangement in the ritual tell us about the community, the individuals and their culture? The movements and practices of bodies require our attention. How is the ritual space measured in terms of bodies and what rhythm do they follow? The distance between bodies and the manner in which they approach each other and keep their distance is significant. What positions do they take? Are they standing or sitting? Which movements do they make when dancing in a school performance or peer group activity? The figurations of bodies are symbolically coded and are used to communicate messages. In terms of gestures, which can be understood as language without words, it is possible to distinguish in education between iconic and symbolic gestures. Iconic gestures are simple "pictorial" gestures with a meaning that is largely independent of the knowledge of a historical time or a particular culture. Such gestures include giving dimensions with simple hand movements or expressing tiredness and the need for sleep by placing the hands together at the side of an inclined head. Symbolic gestures on the other hand have different meanings depending on historical eras and cultures, and exact historical and cultural knowledge is required to understand them. In all cases, the "logic" of the body, its presentation and expression play an important role in the performance of rituals in pedagogy and education. This is especially true for the preconscious perception of bodily expressions which forms the basis with which the atmosphere of ritual arrangements is sensed. The bodies of other people look at us before we become consciously aware of them and they determine our perception of them in this way. In order for the performance of rituals to result in community-forming processes, the children need to experience the flow of energies and force between people - a physical and psychological process which takes place at the outer reaches of our consciousness (Wulf, and Zirfas, 2004, 2005, 2007).

5) Social hierarchies and power structures are staged and placed in context in the ritual performances. This can be illustrated by the example of the inauguration of American presidents. This staged ritual shows that there is only one president. Showing this publicly and transmitting this to the whole world via television is the task to be fulfilled by performing this ritual. The arrangement clearly shows who is the power-bearer. In his speech, the President gives a demonstrative expression of the purposes to which his political power will be used. Ritual power structures are not always so easy to recognize. Butler (1997) has illustrated in several works that ritual repetition is one of the most effective social strategies for establishing and securing power structures in pedagogy and education. Even belonging to a gender is tied to ritual repetitions, which are required to create our initial identities in this respect. Power issues between the genders and generations are also dealt with in everyday rituals at the family breakfast table; this occurs 
in a seemingly casual manner that is all the more effective for its relaxed appearance. Ritual staging and performance allow several matters to be handled simultaneously in pedagogy and education. The coherence of pedagogical and educational settings and communities depends on the distribution of power and therefore the control of this distribution is one of the central tasks of rituals and gestures. A stable balance of power is maintained, regardless whether issues of authority are addressed directly, dealt with in passing or analyzed in detail.

6) Rituals in education and socialization are tied to time and space; their cultural and historical conditions are experienced under these conditions. Different spaces have differing effects on the structure, quality and style of the rituals taking place within them. Ritual spaces differ from physical spaces. On the one hand, they create ritual staging and performance, on the other hand rituals create ritual spaces using body movements, scenarios and symbolic and indexical frames of reference. Educational rituals and spaces have an interactive relationship. In education and socialization both rituals and space are performative. A decorated gymnasium provides the room for a school ball just as a church can stage a confirmation ceremony. However, the school ball also turns the gymnasium into a room of celebration and the confirmation ceremony changes the church into a room of sacred activity. The meshing of real, virtual, symbolic and imaginary space with the bodily movements of those taking part plays an important role in the development of ritual activities.

This inter-connection of real, virtual, symbolic and imaginary space to bodily movements takes place in an environment shaped by historical and cultural factors; this produces an atmosphere which affects the mood of the participants of the ritual. Actions are repeated as part of an attempt to absorb the nature of the atmosphere, structure and function of the space. These actions have taken place here before and the space is suited to their performance. The participants of the ritual change by mimetically recreating the conditions of the space around them. The performative effects of ritual spaces such as the church, the family living room and the virtual space of electronic media are very different and have differing socialization effects.

7) In addition to space, time is the other constituent condition of ritual activity in pedagogy, education, and socialization. There are two complementary views which are important for the manner in which humans deal with time. First, rituals play a vital part in introducing children to the way time is ordered in society. At an early age, parents attempt to adapt the rhythms of childhood to the time rhythms of adult life and therefore even infants grow accustomed to the socially normed manner of handling time. The corresponding rituals and gestures ensure that time becomes the power of order in childhood. Second, ritual activity involving time allows us to glean practical knowledge which is essential for the staging and performance of rituals. Learning to appreciate time is the result of cultural learning processes and rituals play a very important part in this. Their repetitive character inscribes the order of time into the body which then becomes structured by time.

Many rituals are repeated cyclically (Resina, and Wulf, 2019). They serve to secure the presence of the community and to reassert its order and potential for transformation through this repetition. Rituals have the aim of staging continuity, timelessness and unchanging nature of communities and individuals as well as their process and projective character. The ritual treatment of time results in time skills as social skills; ritual ordering of time structures every aspect of social living today.

8) Between the beginning and the end of a ritual in pedagogy and education, there are different sequences of ritual and gestural activity where different practices are expected and conducted. Adherence to rules of ritual activity is closely connected to its sequential character. The ritual practices follow an order which is also a chronological order. The process of rituals creates periods of time which differ from the uniformity of everyday life and become important moments of life. This intensification is achieved by the density of events, their exceptional character and their fast sequence. In many rituals, time is sacred time. Remembrance and ties to the past are therefore constitutive elements of all religions which, with the aid of rituals, transfer canonized content from communicative memory to cultural memory and thereby make it available to its members in a way that it can be used to shape the future. When experiencing sacred time, it is not so much the length of time which is measured but its intensity. On the one hand, rites of passage make it possible to experience different sections of life as phases with their own time scale, on the other hand they create continuity and meaning in the process of life. In the time structures of rituals, certain times often overlap, resulting in highly complex experiences of time.

9) Rituals play an important role in the treatment and handling of difference and alterity in pedagogy and education (Wulf, 2002, 2006a; Dieckmann et al., 1997). In the multi-cultural context of inner city schools, they are important for interaction between children of different ethnicities. They support children to approach others with different cultural backgrounds, overcome differences and live together in harmony. School communities offer examples of both 
success and failures in this area; the imaginary, symbolic and performative elements are equally important here (Huppauf and Wulf 2009; Wulf 2022a).

10) The synchronous and diachronic aspects of mimetic processes are vital for the success of ritual and gestural practices in pedagogy and education. During the performance of rituals and ritual practices, the participants relate immediately and directly to the actions of other participants. This takes place in a largely mimetic manner, using the senses, the movements of the body and the common understanding of words, sounds, language and music. A complete arrangement and complete occurrence of a ritual only takes place when all ritual actions are successfully co-ordinated and precisely orchestrated. Prerequisite for this is the staging, however, the performance itself is the decisive factor, as the ritual actions must be in exact relation to each other. Otherwise the results are farcical and the ritual is deemed as having failed. Harmonious interaction in education requires that the ritual practices relate to each other mimetically. If this happens, energies can "flow" between the ritual participants and they can be experienced as intensive, pleasant and bonding. Just as in dance or wooing, the rational control of actions also has its limits in rituals. The feeling that a ritual has succeeded only occurs if a mimetically-created harmony that is beyond rational control occurs in bodies, movements and gestures. This mimetic occurrence is the basis for the feeling of belonging and community as well as the experience of the sacred (Kress et al., 2021).

Where the synchronic dimension of mimetic processes relates to the importance of mimetic processes in the actual execution of rituals in education, the diachronic dimension relates to the historical aspects of rituals. Rituals in education always relate to others which have taken place - either rituals in which one has participated or rituals of which one has heard an account. This makes the historical dimension a basic condition of rituals. Ritual actions and gestures involve mimetic references to earlier rituals and gestures. As these references are made mimetically, they create an "impression" of earlier performances of the ritual which is then adapted to suit the current context. Depending on the requirements, this process may see the transformation of some aspects of the ritual. Creating a mimetic link between the current and the previous worlds ensures historical continuity in pedagogy and education, which legitimizes the current ritual activity, even if it differs from its predecessor. Mimetic reference does not mean that the ritual is recreated in exactly the same manner every time. Mimetic referencing is "taking on similarities", i.e. the repetition of a similar action which would not be possible if the previous ritual activity had not taken place. In some cases the result of this mimetic referencing also leads to critical distancing from the reference point of the ritual, without this point of reference becoming superfluous. Mimetic referencing enables the current figurations and arrangements of the ritual practice or gesture in pedagogy and education to be updated and modified to suit the context of the current instance. Mimetic constellations, staging styles and types of movement are adapted and changed according to necessity or taste. The "repetition" of earlier rituals does not result in a copy of this ritual in the sense of a copy as made by a photocopier. Rather, this repetition, which makes use of mimetically transferred and assimilated elements, creates something new for all participants whereby the predecessor is dialectically upheld. The ritual which has been updated by this mimetic process integrates the old ritual with a new purpose and a new appearance (Wulf, 2013, 2005, 2022b).

11) There is another important reason that mimetic processes play an essential role in the staging and performing of ritual events and gestures in pedagogy, education and socialization. They enable the learning of the practical knowledge necessary for the ritual practices (Ricoeur 1983-1985; Wulf, 2006b, 2007; Gebauer and Wulf, 1995, 1998, 2003). Ritual knowledge, which allows children to develop the skills required for rituals, evolves from the real or imaginary participation in ritual activities. Children take part in ritual practices by means of mimetic processes; these processes are corporal and are independent actions as well as actions which relate to other ritual ceremonies or arrangements. As part of the mimetic processes, the mimetically-involved child "expands" in terms of the ritual practice. This has the result that the child takes on similarities to the ritual practice due to its bodily nature and its performative character. These processes incorporate ritual figurations, scenes, consequences, images and behavior patterns which are all composite parts of the correct execution of a ritual practice. Rituals connect the past, present, and future. They create continuity and enable historical and cultural change. They are not only guardians of society and culture, they also cause change. Reform and innovation are not possible unless rituals and gestures change. Rituals in education are not static, they are dynamic. The practical knowledge required for their performance which is acquired in mimetic processes means that they are social dramas, and the performative character of these dramas changes social orders. Rituals help to channel the potential for violence present in every society. This is an issue of power and its potential for implementing or preventing social and cultural change.

12) The more monolithic rituals which bestride different areas of life have decreased in importance, a trend caused by the increased focus on this life, religion's disappearance from sight, the differentiation between areas of life and the 
necessity of living in heterogeneous frames of reference. Such major rituals seem to be becoming less important for children. They are being replaced by smaller rituals which relate to specific areas of life and which change according to institution and context. As rituals are becoming more specific, they bring fewer people together than previously. As most children and adults live in several segments of society, they participate in different rituals and rites, of which some are only recognized as such in their own specific area of life. These partial rituals include many leisure-time rituals which one has to complete with a certain degree of skill in order to be accepted into the corresponding group. However, the diversification of ritual activity does not necessarily mean a fundamental loss of significance of rituals. Children and adults need rituals and ritual activities more than ever for the performative creation of partial communities; many rituals evolve which are only valid in a limited context but which are nevertheless indispensable.

\section{Perspectives}

Historical cultural pedagogical anthropology is an anthropology whose rich potential is about to come into its own. It takes into account both the historicity and the culturality of its subject matter and of its own research methods and perspectives, and thus it has a fundamental significance in education and in education studies research. As to its content, there are no limits. The Berlin Study on Rituals and Gestures which I have outlined here is a prime example of research in historical cultural anthropology among (many) others. Rituals produce the social; they form educational fields and communities in the framework of which human beings develop. They are indispensable in the family, at school, in children's and youth culture as well as in the media. For institutions and organizations, they are of constitutive importance. Rituals have safeguarding, but also evolutionary, even innovative functions in pedagogy and education. For too long, this social dynamic of rituals has been obscured, and it is only now that new perspectives thereupon are beginning to emerge. For a reform of pedagogical and educational practices towards the realization of sustainable development, as it has been decided at the UN in autumn 2015, a change of many rituals, gestures and mimetic processes is of central importance for the future of humankind (Kraus and Wulf, 2022; Wulf, 2022b).

\section{References}

Ariès, Philippe, and Duby, Georges. (1985). Histoire de la vie privée, vol. 1-5. Paris: Seuil.

Bell, Catherine. (1992). Ritual Theory, Ritual Practice. New York: Oxford University Press.

Bohnsack, Ralf. (2003). Rekonstruktive Sozialforschung. Einführung in qualitative Methoden. Opladen: Leske und Budrich.

Braudel, Fernand. (1949). La Méditerranée et le monde méditerranéen à l'époque de Philippe II. Paris: A. Colin.

Burke, Peter. (1991). The French Historical Revolution: the Annales School, 1929-89. Stanford: Stanford University Press.

Butler, Judith. (1997). The Psychic Life of Power. Theories in Subjection. Stanford: Stanford University Press.

Dieckmann, Bernhard, Christoph Wulf, and Michael Wimmer (eds.). (1997). Violence. Nationalism, Racism, Xenophobia. Muenster: Waxmann.

Dinzelbacher, Peter (ed.). (1993). Europäische Mentalitätsgeschichte. Hauptthemen in Einzeldarstellungen. Stuttgart: Kroener.

Eigen, Manfred, and Ruthild Winkler-Oswatitsch. (1992). Steps towards Life. A Perspective on Evolution. New York: Oxford University Press.

Evans-Pritchard, Edward Evan. (1965). Theories of Primitive Religion. Oxford: Oxford University Press.

Flick, Uwe. (2007). Designing qualitative research. Thousand Oaks, CA.: Sage Publications.

Flick, Uwe, Ernst von Kardorff, and Ines Teinke (eds.). (2004). A Companion to Qualitative Research. Thousand Oaks, CA: Sage Publications.

Gehlen, Arnold. (1988). Man. His Nature and Place in the World. New York: Columbia University Press.

Gebauer, Gunter, and Wulf Christoph. (1995). Mimesis. Culture, Art, Society. Berkeley: California University Press.

Gebauer, Gunter, and Wulf Christoph. (1998). Spiel, Ritual, Geste. Mimetisches Handeln in der sozialen Welt. Reinbek: Rowohlt (Danish edition 2001; French edition 2004).

Gebauer, Gunter, and Wulf Christoph. (2003). Mimetische Weltzugänge. Soziales Handeln, Rituale und Spiele ästhetische Produktionen. Stuttgart: Kohlhammer. 
Geertz, Clifford. (1973). The Interpretation of Cultures. New York: Basic Books.

Geertz, Clifford. (1993). Local Knowledge. Further Essays in Interpretative Anthropology. London: Fontana.

Gennep, Arnold van. (1960). The Rites of Passage. Chicago: The University of Chicago Press.

Ginzburg, Carlo. (1980). The Cheese and the Worms. The Cosmos of a Sixteenth-Century Miller. Baltimore: Johns Hopkins University Press.

Glaser, Barney, and Anselm Strauss. (1969). The Discovery of Grounded Theory. Chicago: Chicago University Press.

Goffman, Erving. (1959). The Presentation of Self in Every Day Life. New York: Doubleday Archor.

Goffman, Erving. (1986). Frame Analysis. An Essay of the Organization of Experience. Boston: Northeastern University Press.

Grimes, Ronald. (1995). Beginnings in Ritual Studies. Columbia: University of South Carolina Press.

Harris, Marvin. (2001). The Rise of Anthropological Theory. A History of Theories of Cultures. Walnut Creek/CA: Altamira Press.

Huppauf, Bernd, and Christoph Wulf (eds.). (2009). Dynamics and Performativity of Imagination. The Image between the Visible and the Invisible. New York: Routledge.

Kant, Immanuel. (1982). Schriften zur Anthropologie, Geschichtsphilosophie, Politik und Pädagogik 2. Frankfurt/M.: Suhrkamp.

Kraus, Anja, and Wulf, Christoph (eds.) (2022). Handbook of Embodiment and Learning. London: Palgrave Macmillan.

Kress, Gunter, Selander, Staffan, Saljö, Roger, and Wulf, Christoph (eds.) (2021). Learning as Social Practice. Beyond Education as an Individual Enterprise. London et al.: Routledge.

Malinowski, Bronislaw. (1922). Argonauts of the Western Pacific. London: G. Routledge \& Sons.

Lévi-Strauss, Claude. (1992). Tristes tropiques. New York: Atheneum.

Martin, Jochen. (1994). Der Wandel des Beständigen. Überlegungen zu einer historischen Anthropologie." Freiburger Universitätsblätter. 126.

Medick, Hans. (1989). 'Missionare im Ruderboot.' Ethnologische Erkenntnisweisen als Herausforderung an die Sozialgeschichte. In Alltagsgeschichte. Zur Rekonstruktion historischer Erfahrungen und Lebensweisen, ed. Alf Luedtke. Frankfurt/M. and New York: Lang, 48-84.

Mead, Margaret. (1950). Sex and Temperament in Three Primitive Societies. New York: New American Library.

Morin, Edgar. (1973). Le paradigme perdu. Paris: Seuil.

Plessner, Helmuth. (1970). Laughing and crying. A study of the limits of human behavior. Evanston: Northwestern University Press.

Resina, Joan Ramon and Wulf, Christoph (eds). (2019). Repetition, Recurrence, Returns: How Cultural Renewal Works. Lanham, MD: Lexington Books.

Ricoeur, Paul. (1983-1985). Time and Narrative I-III. Chicago and London: University of Chicago Press.

Sahlins, Marshall. (1976). Culture and Practical Reason. Chicago: Chicago University Press 1976.

Schechner, Richard. (1977). Essays on Performance Theory 1970-1976. New York: Drama Book Specialists.

Tambiah, Stanley. (1979). A Performative Approach to Ritual. Proceedings of the British Academy 65, 113-63.

Strauss, Anselm, and Juliet Corbin. (1994). Grounded Theory: An Overview. In Handbook of Qualitative Research, ed. Norman K. Denzin and Yvonne S. Lincoln. Thousand Oaks: Sage, 273-85.

Turner, Victor. (1969). The Ritual Process: Structure and Anti-Structure. Chicago: Aldine Pub. Co.

Turner, Victor. (1982). From Ritual to Theatre. The Human Seriousness of Play. New York: PAJ Publications.

Weinberg, Steven. (1993). The First Three Minutes. A Modern View of the Origin of the Universe. New York: Basic Books.

Wulf, Christoph (ed.). (1997). Vom Menschen. Handbuch Historische Anthropologie. Weinheim and Basel: Beltz (French and Italian edition 2002; Japanese edition 2008). 
Wulf, Christoph. (2002). Anthropology of Education. Muenster and New York: Lit. (French edition 1999; German edition 2001; Spanish edition 2002; Roumaninan edition 2007).

Wulf, Christoph. (2005). Zur Genese des Sozialen: Mimesis, Performativität, Ritual. Bielefeld: transcript (French edition 2007; Russian edition 2009).

Wulf, Christoph. (2006a). Anthropologie kultureller Vielfalt. Interkulturelle Bildung in Zeiten der Globalisierung. Bielefeld: transcript.

Wulf, Christoph. (2006b). Praxis. In Theorizing Rituals. Issues, Topics, Approaches, Concepts, ed. Jens Kreinath, Jan Snoek, and Michael Strausberg. Leiden and Boston: Brill, 395-411.

Wulf, C. (2013). Anthropology: A Continental Perspective. Chicago: Chicago University Press.

Wulf, Christoph, et al. (2001). Das Soziale als Ritual. Zur performativen Bildung von Gemeinschaften. Opladen: Leske und Budrich (French edition 2004).

Wulf, Christoph, et al. (2004). Bildung im Ritual. Schule, Familie, Jugend, Medien. Wiesbaden: VS Verlag für Sozialwissenschaften.

Wulf, Christoph, et al. (2007). Lernkulturen im Umbruch. Wiesbaden: VS Verlag für Sozialwissenschaften.

Wulf, C., et al. (2010). Ritual and Identity: The Staging and Performing of Rituals in the Lives of Young People. London: The Tufnell Press.

Wulf, Christoph, et al. (2011). Gesten in Erziehung, Bildung und Sozialisation. Wiesbaden: VS Verlag für Sozialwissenschaften.

Wulf, Christoph (2022a). Human Beings and their Images. Imagination, Mimesis, Performativity. London: Bloomsbury.

Wulf, Christoph (2022b). Education as Human Knowledge. An Anthropological Perspective. London: Routledge.

Wulf, Christoph, Michael Göhlich, and Jörg Zirfas. (2001). Grundlagen des Performativen. Eine Einführung in die Zusammenhänge von Sprache, Macht und Handeln. Weinheim and München: Juventa.

Wulf, Christoph, and Dietmar Kamper (eds.) (2002). Logik und Leidenschaft. Berlin: Reimer.

Wulf, Christoph, and Jörg Zirfas (eds.). (2004). Die Kultur des Rituals. München: Wilhelm Fink.

Wulf, Christoph, and Jörg Zirfas (eds.) (2005). Ikonologie des Performativen. München: Wilhelm Fink.

Wulf, Christoph, and Jörg Zirfas (eds.). (2007). Die Pädagogik des Performativen. Weinheim and Basel: Beltz.

Citethis article as: Christoph Wulf (2021). TheBerlin ritual and gesturestudy. A contribution to pedagogical anthropol ogy. International Journal of Education and Teaching. 1(2), 16-29. doi: 10.51483/ IJEDT.1.2.2021.16-29. 